\title{
The Response of Cotton to Fertilizers in Puerto Rico
}

\author{
G. Samuels, J. P. Rodríguez, and P. Landrau, $J r^{1}$
}

\section{INTRODUCTION}

Cotton was cultivated in Puerto Rico even before the landing of Columbus in the West Indies, but it was not until $\mathbf{1 7 7 6}$ that the growers showed interest in large-scale production of this textile. Following this, cotton took an important place among the crops of economic value under cultivation in Puerto Rico. Interest in this commodity has grown and waned in the last 25 years to such extent that the production was as high 42,044 hundredweights in $1942(8)^{2}$ and as low as 664 hundredweights in $1957(1)$.

The major cotton-growing area is in the northwestern part of Puerto Rico with its center in Isabela. Other important centers in this area are Quebradillas, Camuy, and Hatillo. The southwestern part of the Island produces only a limited amount of the total cotton, in the municipalities of Cabo Rojo, Lajas, and Sabana Grande. Individual cotton plantings are small, the average field being about 2 acres. Most of the work is done by hand, usually by the farmer and his family. Fertilizer accounts for most of the cash outlay, if and when it is used.

Very little research has been published concerning cotton fertilizers for Puerto Rico.

Chardón, in 1929-30 (4), recommended that, for the Isabela area, a fertilizer higher in potash, such as the 8-12-12, should be substituted for the then popular 5-9-5. Capó (2) reported response of Sea Island cotton (Montserrat variety) to 82 pounds of nitrogen per acre, but no response to additional nitrogen, or to applications of phosphorus or potash, when grown in Coto clay at Mantilla Farm, Isabela.

\section{OBJECTIVE}

Experiments have been conducted by the Agricultural Experiment Station of the University of Puerto Rico to determine whether fertilizers would benefit cotton growers by increasing yields. The technique of foliar diagnosis was also tried for cotton to determine whether it would reveal the fertilizer requirements of the cotton crop. This paper reports the results of these experiments.

1 Agronomist, Agronomist, and former Associate Agronomist, respectively, Agri. cultural Experiment Station, University of Puerto Rico, Río Piedras, P.R.

2 Italic numbers in parentheses refer to Literature Cited, p. 101-2. 


\section{SOILS AND PROCEDURES}

There were six fertilizer experiments in all-two at Isabela, two at Aguirre, and two at Lajas.

One experiment at Isabela was conducted at the Mantilla Farm, Arenales, on a Coto clay (2). The Coto clay is a permeable yellowish-colored clay derived from Tertiary limestone, and its $\mathrm{pH}$ ranges normally from $\mathbf{5 . 5}$ to 6.5. A paired-plot design was used in the experiment, replicated seven times. The plot size was 27 by 30 feet, each consisting of nine rows 3 feet apart with 30 inches between plants in the row. The experiment was planted with Sea Island cotton (Montserrat variety) on March 18, 1943, and harvested from August 10, 1943 to September 10, 1943.

The other experiment at Isabela was conducted at the farm of Don Juan Abreu at Bejucos where the soil was a Guayabo fine sand. Guayabo fine sand is characterized by a deep layer of grayish-brown fine sand overlying a mottled compact stiff subsoil. It occurs in undulating or rolling areas in the vicinity of Isabela. This soil is within the Isabela irrigation project, but it is so sandy that very few areas are irrigated. A triple-lattice design was used in the experiment, replicated six times with major- and minorelement treatments. The plot size was 18 by 24 feet each, consisting of six rows 4 feet apart with 30 inches between plants in the row. The experiment was planted with Sea Island cotton on October 12, 1950, and harvested from March 8 to April 19, 1951.

At Aguirre, the experiment at Colonia Florida, Central Cortada, was located on a Santa Isabel silty clay loam. This soil occurs on the nearly level well-drained alluvial fans and in terracelike positions along the semiarid southern coast. The Santa Isabel silty clay loam is characterized by an alkaline friable light-brown silty clay loam with a subsoil that is a very heavy compact brown calcareous plastic clay. Nearly all of the land is used for the production of sugarcane, except in places where salt content of the surface soil is greater than 0.2 percent. The experimental design used was a simple randomized-block one having four replications. The plot size was 23 by 3 feet with seven rows 41 inches apart and 36 inches long. The experiment was fertilized on August 5, 1952, planted with Sea Island cotton the next day, and harvested from January 3 to March 19, 1953.

The Colonia Fortuna, Aguirre, experiment was made on an Altura loam. This soil is developed from alluvial material that has been washed from the steep hills of the southern side of the Cordillera Central. It occurs in several areas near the foothills between Guayama and Juana Díaz. It is one of the most productive soils in the Island, and nearly the entire area is planted to sugarcane where irrigation is possible. The experimental design and plot size used were the same as for the Colonia Florida experiment, except that there were nine replications. Fertilizer was applied on August 17, 
1952 , the field was planted to the Sealand variety of cotton 3 days later, and was harvested from December 12, 1953 to February 20, 1954.

The two experiments at the Lajas Substation were performed on a Santa Isabel clay. This soil is characterized by an alkaline granular heavy-clay surface soil about 1 foot thick. The soil is plastic and sticky when wet and ranges in color from a light brown to a very dark brown or nearly black, depending on rainfall. Nearly the entire area of this soil that is irrigated and does not contain harmful soluble salts is used for sugarcane.

The fertilizer-variety experiment was a split-plot in design with five cotton varieties on the main plots and four fertilizer levels on the subplots. The main plots, which were replicated five times, were 32 by 60 feet, divided into four subplots 16 by 30 feet each. The subplot consisted of four rows 48 inches apart and 30 feet long, with distances of 24 inches between plants in the row. The experiment was planted September 21, 1953 and harvested from February 8 to June 23, 1954.

The fertilizer-planting-distance experiment was also in split-plot design with four planting distances on the main plots and eight fertilizer levels on the subplots. The main plots which were replicated four times, were 64 by 14 feet. The subplot size was 14 by 14 feet, with four rows 42 inches apart. The experiment was planted with Sea Island cotton on July 1, 1955, and harvested from December 15, 1955 to March 12, 1956.

All experiments, except the one on Guayabo fine sand at Isabela, received supplemental irrigation when needed. The fertilizers for all experiments, except the two at Aguirre, were applied at the time of the thinning of the cotton plants -approximately 2 weeks after planting. The source of nitrogen used was ammonium sulfate (20-percent $N$ ); of phosphorus, superphosphate (20-percent $\mathrm{P}_{2} \mathrm{O}_{5}$ ) ; and of potash, potassium chloride (60-percent $\mathrm{K}_{2} \mathrm{O}$ ).

To insure a good stand of cotton in the experiments performed since 1951 Aldrin (25-percent) was applied to the soil at the rate of 1 gallon per acre before planting for control of soil insects such as mole crickets (Scapteriscus vicinus Scudder), white grubs (Phyllophaga spp.), and cutworms. The cotton plants in the experiments were sprayed every 15 days with DDT at the rate of 4 pounds per 100 gallons of water, to check the development of pink bollworms (Pectinophora gossypiella Saunders). At Aguirre, BHC was added to the DDT spray to check the cotton aphids, and at the Lajas Substation two sprays with Chlordane at the rate of 1 quart per acre were made to check the cotton leaf worms (Alabama argillacea Hubner). Unfortunately, such chemical control measures for the pink bollworm and other insects attacking cotton were not available in Puerto Rico before 1950-51, when the two Isabela experiments were performed, and large reductions in yields occurred because of insect damage. 
Leaf samples of the cotton leaves were taken from the Aguirre and Lajas experiments. The leaves from the third and fourth nodes from the apex of the main stem were used. Three plants were sampled per row or, usually, 12 plants per plot. The leaf samples were taken in the morning before 9 a.m. The leaf blade was separated from the petiole. The cotton leaves were dried at $75^{\circ} \mathrm{C}$. for 12 hours then ground in a Wiley mill. The analyses for nitrogen, phosphorus, and potassium were performed by the Central Analytical Laboratory of the Experiment Station, using methods described in an earlier publication (3).

TABLE 1.-Influence of fertilizers on Sea Island collon yields at Isabela on a Coto clay, 1948

\begin{tabular}{c|r|r|r|r}
\hline \multirow{2}{*}{ Treatment No. } & \multicolumn{3}{|c|}{ Treatment per acre with } & $\begin{array}{c}\text { Mean yield of seed cotton } \\
\text { per acre }\end{array}$ \\
\cline { 2 - 4 } & $\mathrm{N}$ & $\mathrm{P}_{2} \mathrm{O}_{6}$ & $\mathrm{~K}_{3} \mathrm{O}$ & \\
\hline & $L b$. & $L b$. & $L b$. & $C w t$. \\
1 & 0 & 0 & 0 & 5.14 \\
2 & 0 & 200 & 200 & 5.11 \\
3 & 100 & 200 & 200 & 7.33 \\
4 & 200 & 0 & 200 & 6.54 \\
5 & 200 & 100 & 200 & 6.73 \\
6 & 200 & 200 & 0 & 7.40 \\
7 & 200 & 200 & 100 & 7.53 \\
8 & 200 & 200 & 200 & 7.34 \\
\hline \hline
\end{tabular}

\section{RESULTS}

\section{FERTILIZER EXPERIMENTS}

Because the fertilizer experiments covered different areas of the Island and involved more than one soil series, the results will be presented by soils.

\section{Coto clay}

The only significant response on Coto clay was to 82 pounds of nitrogen per acre (table 1). There were no significant responses to phosphates nor potash. The Coto clay has shown responses, in yields of sugarcane (4) and tomatoes $(5)$, to phosphates and nitrogen and, for pineapples $(8)$, to nitrogen and potash. 


\section{Guayabo fine sand}

Although the Guayabo fine-sand experiment suffered from a severe attack of pink bollworm, the yield data still indicated a response to various fertilizer treatments. There was a significant response to phosphate and potash fertilizers, but not to nitrogen (table 2). The addition of 100 pounds each

TABLE 2.-Influence of fertilizers on Sea Island cotton yields at Isabela on a Guayabo fine sand, 1951-62

\begin{tabular}{|c|c|c|c|c|c|c|}
\hline \multirow{2}{*}{$\begin{array}{c}\text { Treatment } \\
\text { No. }\end{array}$} & \multicolumn{3}{|c|}{ Treatment per acre with - } & \multicolumn{2}{|c|}{ Minor elements } & \multirow{2}{*}{$\begin{array}{l}\text { Mean yields of } \\
\text { seed cotton per } \\
\text { acre }\end{array}$} \\
\hline & $\mathbf{N}$ & $\mathrm{P}_{3} \mathrm{O}_{6}$ & $\mathrm{~K}_{2} \mathrm{O}$ & Compounds used & $\begin{array}{l}\text { Rate per } \\
\text { acre }\end{array}$ & \\
\hline & $L b$. & $L b$. & $L b$. & & $L b$. & Crot. \\
\hline 1 & 0 & 0 & 0 & 一 & 一 & 1.4 \\
\hline 2 & 0 & 200 & 200 & - & - & 4.7 \\
\hline 3 & 82 & 200 & 200 & - & - & 4.9 \\
\hline 4 & 165 & 0 & 200 & - & - & 3.0 \\
\hline 5 & 165 & 100 & 200 & - & - & 4.3 \\
\hline 6 & 165 & 200 & 0 & - & - & 2.9 \\
\hline 7 & 165 & 200 & 100 & - & - & 5.0 \\
\hline 8 & 165 & 200 & 200 & - & - & 4.6 \\
\hline 9 & 165 & 200 & 200 & Copper sulfate & 100 & 4.1 \\
\hline 10 & 165 & 200 & 200 & Magnesium oxide & 1,000 & 4.6 \\
\hline 11 & 165 & 200 & 200 & Magnesium sulfate & 300 & 5.0 \\
\hline 12 & 165 & 200 & 200 & do. & 100 & 5.0 \\
\hline 13 & 165 & 200 & 200 & Zinc sulfate & 45 & 4.6 \\
\hline 14 & 165 & 200 & 200 & Borax & 25 & 4.8 \\
\hline 15 & 165 & 200 & 200 & do. & 50 & 4.0 \\
\hline 16 & 165 & 200 & 200 & Boric acid & 1 & 3.1 \\
\hline \multicolumn{6}{|c|}{$\begin{array}{l}\text { Least significant difference needed between treatment means for: } \\
5 \text {-percent level } \\
1 \text {-percent level }\end{array}$} & $\begin{array}{l}1.31 \\
1.75\end{array}$ \\
\hline
\end{tabular}

${ }_{1}^{1}$ Seed were pretreated by soaking for 24 hours at room temperature in a 0.4 -percent solution of boric acid $\left(\mathrm{H}_{3} \mathrm{BO}_{3}\right)$ before planting.

of phosphate $\left(\mathrm{P}_{2} \mathrm{O}_{5}\right)$ and potash $\left(\mathrm{K}_{2} \mathrm{O}\right)$ per acre gave an increase of twothirds more seed cotton than when these fertilizer materials were omitted. Nitrogen, whether as ammonium sulfate, or sodium nitrate, did not increase yields. Work by Chardón (4), in 1929-30, on the very same Guayabo fine sand showed large responses to phosphate and potash with little response to nitrogen. Yields were highest where 800 pounds per acre of a 8-12-12 mixed fertilizer were applied. Similar responses of cotton to phosphates and potash were also obtained with a Sabana Seca sandy loam at Isabela by Chardón (4). 
The results of the experiments conducted to date on the Guayabo fine sand indicate that higher levels of phosphate and potash are needed than of nitrogen. The use of about 1,000 pounds of a 5-10-10 per acre is preferable for this soil.

There were no significant responses in cotton yields to any of the minorelement treatments used on the Guayabo fine sand. These treatments included such minor elements as copper, magnesium, manganese, zinc, and boron (table 1).

TABLE 3.-The influence of fertilizers on the yields of Sealand cotton at Aguirre on an Altura loam, 1958-54

\begin{tabular}{|c|c|c|c|c|}
\hline \multirow{2}{*}{ Treatment No. } & \multicolumn{3}{|c|}{ Treatment per acre with - } & \multirow{2}{*}{$\begin{array}{l}\text { Mean yields of seed cotton } \\
\text { per acre }\end{array}$} \\
\hline & $\mathbf{N}$ & $\mathrm{P}_{2} \mathrm{O}_{6}$ & $\mathrm{~K}_{2} \mathrm{O}$ & \\
\hline $\begin{array}{l}1 \\
2 \\
3 \\
4 \\
5 \\
6\end{array}$ & $\begin{array}{r}L b . \\
0 \\
0 \\
100 \\
200 \\
200 \\
200\end{array}$ & $\begin{array}{r}L b . \\
0 \\
50 \\
50 \\
0 \\
50 \\
50\end{array}$ & $\begin{array}{r}L b . \\
0 \\
75 \\
75 \\
75 \\
0 \\
75\end{array}$ & $\begin{array}{c}\text { Cwt. } \\
15.7 \\
15.3 \\
19.5 \\
10.7 \\
19.8 \\
21.5\end{array}$ \\
\hline \multicolumn{4}{|c|}{$\begin{array}{l}\text { Least significant differences needed between treatment mean } \\
\text { for: } \\
\text { 5-percent level } \\
\text { 1-percent level }\end{array}$} & $\begin{array}{l}2.51 \\
3.39\end{array}$ \\
\hline
\end{tabular}

\section{Altura loam}

The only significant response obtained on Altura loam was to nitrogen applications of 100 pounds per acre (table 3 ). Results from the use of 200 pounds per acre of nitrogen as compared to 100 (table 3, treatment $3 \mathrm{vs}$. treatment 6 ) were not significant. There were no responses to phosphates at 50 pounds of $\mathrm{P}_{2} \mathrm{O}_{5}$ per acre nor potash at 75 pounds of $\mathrm{K}_{2} \mathrm{O}$ per acre. The cotton variety planted here was Sealand instead of the more commonly planted Montserrat Sea Island.

\section{Santa Isabel silty clay loam}

There were no responses to nitrogen, phosphates, nor potash fertilizer by cotton growing in Santa Isabel silty clay loam. Nitrogen was applied at rates up to 200 pounds of $\mathrm{N}$ per acre, phosphates and potash up to 100 pounds of $\mathrm{P}_{2} \mathrm{O}_{5}$ and $\mathrm{K}_{2} \mathrm{O}$ per acre, respectively. Yields of seed cotton averaged 23 hundredweights per acre for all treatments. The variety planted here was Sea Island. 


\section{Santa Isabel clay}

There was a response to nitrogen for both experiments performed on Santa Isabel clay. In the variety experiment (table 4), the mean of the five varieties tested showed a significant response to nitrogen. There was a difference in the intensity of response between the various varieties. Sealand showed a large response to nitrogen applications with an increase of 8.4 hundredweights, or 44 percent, compared with the no-nitrogen application (table 4). However, the other varieties failed to show such marked response

TABLE 4.-The yields of 5 collon varieties grown at different fertilizer levels on a Santa Isabel clay at the Lajas Substation, 1958-54

\begin{tabular}{|c|c|c|c|c|c|c|c|c|c|}
\hline \multirow[b]{2}{*}{ Treatment No. } & \multicolumn{3}{|c|}{ Treatment per acre with - } & \multicolumn{6}{|c|}{ Mean yields of indicated cotton variety per acre } \\
\hline & $\mathbf{N}$ & $\mathrm{P}_{2} \mathrm{O}_{3}$ & $\mathbf{K}_{\mathbf{2}} \mathrm{O}$ & $\begin{array}{c}\text { Sea } \\
\text { Island }\end{array}$ & Pima & $\begin{array}{c}\text { Coast- } \\
\text { land }\end{array}$ & Sealand & Amsak & $\begin{array}{l}\text { Means } \\
\text { of } 5 \\
\text { varieties }\end{array}$ \\
\hline $\begin{array}{l}1 \\
2 \\
3 \\
4\end{array}$ & $\begin{array}{r}L b . \\
0 \\
200 \\
200 \\
200\end{array}$ & $\begin{array}{r}L b . \\
200 \\
0 \\
200 \\
200\end{array}$ & $\begin{array}{r}L b . \\
200 \\
200 \\
0 \\
200\end{array}$ & $\begin{array}{r}\text { Cwt. } \\
16.0 \\
16.9 \\
18.3 \\
18.7\end{array}$ & $\begin{array}{r}\text { Cwt. } \\
9.0 \\
7.3 \\
8.8 \\
10.4\end{array}$ & $\begin{array}{r}\text { Crot. } \\
12.0 \\
12.1 \\
14.5 \\
14.2\end{array}$ & $\begin{array}{r}C w t . \\
19.1 \\
23.0 \\
25.3 \\
27.5\end{array}$ & $\begin{array}{r}\text { Czut. } \\
9.4 \\
9.8 \\
10.6 \\
12.2\end{array}$ & $\begin{array}{r}\text { Cwt. } \\
13.9 \\
13.8 \\
15.5 \\
16.6\end{array}$ \\
\hline \multicolumn{4}{|c|}{ Variety means ${ }^{1}$} & 17.5 & 8.9 & 13.2 & 23.7 & 10.5 & - \\
\hline \multicolumn{4}{|c|}{$\begin{array}{l}\text { I.cast significant difference needed } \\
\text { between treatment means for: } \\
\text { 5-percent level } \\
\text { 1-percent level }\end{array}$} & $\begin{array}{l}2.94 \\
3.92\end{array}$ & $\begin{array}{l}2.94 \\
3.92\end{array}$ & $\begin{array}{l}2.94 \\
3.92\end{array}$ & $\begin{array}{l}2.94 \\
3.92\end{array}$ & $\begin{array}{l}2.94 \\
3.92\end{array}$ & $\begin{array}{l}1.32 \\
1.76\end{array}$ \\
\hline
\end{tabular}

${ }^{1}$ Least significant difference needed between varieties for 5 -percent level 2.07 and 1 -percent level 2.85 .

to nitrogen. Amsak gave a 30-percent increase in yield when nitrogen was applied and the remaining three varieties a 17 -percent increase.

The response to nitrogen was high for the fertilizer-spacing experiment, amounting to 5 hundredweights of seed cotton, or an increase of 38 percent (table 5, treatment $2 v s$. treatment 8). This response to nitrogen was greater for the Sea Island cotton in this experiment than in the variety-fertilizer experiment (table 4).

Only in the variety experiment did the application of phosphate fertilizers boost cotton yields (table 4). In fact, the increases attributable to phosphates averaged the same as those from nitrogen. Once again, there was a difference in varietal response to phosphate applications. Pima responded most to phosphate, with a 43-percent yield increase, while the remaining four varieties averaged a 17 -percent increase. Sea Island cotton, 
which failed to register a significant increase in yield for phosphorus fertilizers (table 4), also failed to respond in the fertilizer planting-distance experiment (table 5).

There was no significant response to potash fertilizers for any of the varieties tested, nor for any of the planting distances used.

There were no significant increases in yields of cotton at any of the four planting distances used: $12,18,24$, and 30 inches between plants. Neither were there any interactions of planting distances with fertilizers in the fer-

TABLE 5.-The influence of fertilizers and planting distance ${ }^{1}$ on cotton yields, on a Sanla Isabel clay, at Lajas Substation, 1955-56

\begin{tabular}{|c|c|c|c|c|}
\hline \multirow{2}{*}{ Treatment No. } & \multicolumn{3}{|c|}{ Treatment per acre with - } & \multirow{2}{*}{$\begin{array}{c}\text { Mean yields of seed cotton } \\
\text { per acre }\end{array}$} \\
\hline & $\mathbf{N}$ & $\mathrm{P}_{2} \mathrm{O}_{6}$ & $\mathrm{~K}_{2} \mathrm{O}$ & \\
\hline $\begin{array}{l}1 \\
2 \\
3 \\
4 \\
5 \\
6 \\
7 \\
8\end{array}$ & $\begin{array}{r}L b . \\
0 \\
0 \\
50 \\
100 \\
100 \\
100 \\
100 \\
100\end{array}$ & $\begin{array}{r}L b . \\
0 \\
100 \\
100 \\
0 \\
50 \\
100 \\
100 \\
100\end{array}$ & $\begin{array}{r}L b . \\
0 \\
100 \\
100 \\
100 \\
100 \\
0 \\
50 \\
100\end{array}$ & $\begin{array}{l}\text { Cwt. } \\
13.3 \\
13.4 \\
16.7 \\
18.2 \\
18.3 \\
18.6 \\
18.6 \\
18.3\end{array}$ \\
\hline \multicolumn{4}{|c|}{$\begin{array}{l}\text { Least significant difference needed between treatment means } \\
\text { for: } \\
\text { 5-percent level } \\
\text { 1-percent level }\end{array}$} & $\begin{array}{l}1.69 \\
2.24\end{array}$ \\
\hline
\end{tabular}

${ }^{1}$ Data not shown; see text p. 96, above and below table 5 .

tilizer-planting-distance experiment. Therefore, the data for this portion of the experiment are not presented in table 5.

Fertilizer demands appeared to be highest for nitrogen and phosphorus, with no response to potash in the Santa Isabel clay. The intensity of these needs seemed to vary somewhat with the cotton variety planted.

\section{FOLIAR DIAGNOSIS}

The results obtained from leaf sampling of the cotton, although not conclusive, were of sufficient value to indicate that foliar diagnosis may be helpful in determining the fertilizer requirements of cotton.

Early in the sampling it was found that leaf-blade samples were higher in both nitrogen and phosphorus than the petiole. Leaf petioles were higher in potassium, but even here the range of potassium encountered in the 
leaf blade was ample. Therefore, leaf-blade tissue was utilized for all subsequent leaf samples. The values obtained for the leaf blade and petiole are given in table 6 .

When to take leaf samples for the best indication of the plant's fertility is an important question. It is complicated by its value for practical use. In other words, if the best time for indication of the crop's fertilizer needs is near harvesttime, the results obtained are of little or no practical use for the crop sampled. Early leaf sampling is needed for such a rapid-growing and short-lived crop as cotton, otherwise the results obtained could not be translated into corrective fertilizer applications in time.

From results obtained from the Altura loam at Aguirre (table 7) it appeared that leaf samples taken at 45 days revealed the greatest difference in the response of the cotton plant to fertilizers. Except for leaf phosphorus, all leaf-nutrient values tended to decrease with age. This was especially true for nitrogen. Joham (5) found that sampling at 90 days after planting

TABLE 6.-The nutrient conlent (percent) of leaf blades and petioles of Sea Island cotton

\begin{tabular}{|c|c|c|c|}
\hline \multirow{2}{*}{ Leaf tissue } & \multicolumn{3}{|c|}{ Nutrient content of cotton leaft on dry-weight basis for - } \\
\hline & Nitrogen & Phosphorus & Potassium \\
\hline $\begin{array}{l}\text { Blade } \\
\text { Petiole }\end{array}$ & $\begin{array}{l}4.48(4.28-4.69) \\
1.46(1.28-1.78)\end{array}$ & $\begin{array}{r}0.33(0.30-0.38) \\
18(0.13-.21)\end{array}$ & $\begin{array}{l}2.76(2.51-2.95) \\
4.42(4.18-4.82)\end{array}$ \\
\hline
\end{tabular}

${ }^{1}$ Sampled 45 days after planting. Range in parentheses.

gave the highest significant correlation between the concentration of the elements in the petiole and the nutrient treatment. However, correlation values at 60 days were not very much lower. Petiole samples taken at 30 and 145 days had low concentrations of the elements in the petiole. The authors have found that, for sugarcane (9) and pineapples (11), leaf-nutrient values also tended to decrease with age.

Ieaf sumpling cotton at 45 days would allow time for corrective fertilizer side-dressings to the crop, if they were made within a week or two after the leaf samples were taken. Leaf samples at 30 days, as indicated by Joham's work (5), showed that the plant has not reached an equilibrium with the fertilizer applied. To take leaf samples after $\mathbf{4 5}$ days limits their effective use for correction of the fertilizer deficiencies of the crop sampled.

Using the data from table 7, leaf-nutrient values can be indicated for optimum yields of Sea Island cotton on an Altura loam when these samples are taken about 45 days after planting. Leaf values of 4.75 percent and above would indicate no significant need for nitrogen fertilizers. For phosphorus, leaf values of 0.36 percent and above, and for potassium, leaf values 
of 3.10 and higher, indicate no significant need for phosphates or potash. But, as these fertilizers did not significantly influence yield (table 3), even

TABLE 7.-The influence of fertilizer applications and time of sampling on the leafnutrient content of cotton leaves, Sea Island variety, Aguirre, 1952-58

\begin{tabular}{|c|c|c|c|c|c|c|}
\hline \multicolumn{3}{|c|}{ Treatment per acre with - } & \multicolumn{3}{|c|}{$\begin{array}{l}\text { Nutrient content, dry-weight basis, for leaf } \\
\text { samples taken at - }\end{array}$} & \multirow{2}{*}{$\begin{array}{l}\text { Relative yields of } \\
\text { seed cotton per acre }\end{array}$} \\
\hline $\mathbf{N}$ & $\mathbf{P}_{2} \mathrm{O}_{6}$ & $\mathbf{K}: \mathbf{O}$ & 45 days & 60 days & 90 days & \\
\hline \multicolumn{7}{|c|}{ Leaf-nitrogen $(N)$} \\
\hline$L b$. & $L b$. & $L b$. & Percent & Percent & Percent & \\
\hline 0 & 50 & 75 & 4.20 & 4.20 & 3.48 & 70 \\
\hline 100 & 50 & 75 & 4.76 & 4.24 & 3.69 & 89 \\
\hline 200 & 50 & 75 & 5.10 & 4.30 & 3.78 & 100 \\
\hline \multicolumn{3}{|c|}{ Average of 3 treatments } & 4.73 & 4.24 & 3.58 & \\
\hline $\begin{array}{r}\text { Differe } \\
200 \\
\text { tre }\end{array}$ & $\begin{array}{l}\text { betwe } \\
\text { nd N } \\
\text { nt }\end{array}$ & $\begin{array}{l}\text { and } \\
\text { acre }\end{array}$ & 0.90 & 0.10 & 0.31 & \\
\hline
\end{tabular}

Leaf phosphorus $(P)$

\begin{tabular}{|c|c|c|c|c|c|c|}
\hline $\begin{array}{l}200 \\
200\end{array}$ & $\begin{array}{r}0 \\
50\end{array}$ & $\begin{array}{l}75 \\
75\end{array}$ & $\begin{array}{r}0.36 \\
.41\end{array}$ & $\begin{array}{r}0.39 \\
.41\end{array}$ & $\begin{array}{r}0.44 \\
.44\end{array}$ & $\begin{array}{r}91 \\
100\end{array}$ \\
\hline \multicolumn{3}{|c|}{ Average of 2 treatments } & 0.39 & 0.40 & 0.44 & \\
\hline \multicolumn{3}{|c|}{$\begin{array}{l}\text { Difference between } 0 \text { and } 50 \\
\text { pounds } \mathrm{P}_{2} \mathrm{O}_{5} \text { per acre } \\
\text { treatment }\end{array}$} & 0.05 & 0.02 & 0 & \\
\hline
\end{tabular}

Leaf polassium $(K)$

\begin{tabular}{|c|c|c|c|c|c|c|}
\hline $\begin{array}{l}200 \\
200\end{array}$ & $\begin{array}{l}50 \\
50\end{array}$ & $\begin{array}{r}0 \\
75\end{array}$ & $\begin{array}{l}3.07 \\
3.21\end{array}$ & $\begin{array}{l}2.30 \\
2.38\end{array}$ & $\begin{array}{l}2.32 \\
2.32\end{array}$ & $\begin{array}{r}91 \\
100\end{array}$ \\
\hline \multicolumn{3}{|c|}{ Average of 2 treatments } & 3.14 & 2.34 & 2.32 & \\
\hline \multicolumn{3}{|c|}{$\begin{array}{l}\text { Difference between } 0 \text { and } 75 \\
\text { pounds } \mathrm{K}_{2} \mathrm{O} \text { per acre } \\
\text { treatment }\end{array}$} & 0.14 & 0.08 & 0 & \\
\hline
\end{tabular}

lower values of leaf phosphorus and potassium might be indicative of negative yield responses.

The fertilizer-variety experiment at the Lajas Substation was leaf-sampled. The values obtained enabled us to observe any noticeable differences 
in leaf-nutrient values for cotton varieties, and, from table 8 , cotton varieties do differ in their leaf-nutrient values as they do in yields. Sealand, which gave the highest yields of seed cotton (table 4), did not have the highest leaf-nutrient values. Pima, which gave the lowest cotton yields, did not have the lowest leaf-nutrient values. The differences obtained in leafnutrient values between varieties at the various fertilizer levels indicate that it may be necessary to establish separate standard leaf-nutrient levels for certain cotton varieties.

TABLE 8.-The influence of fertitizer applicatons on the leaf-nutrient content of cotton leaves from 5 varieties and their relative yields at the Lajas Substation, 1958-541

\begin{tabular}{|c|c|c|c|c|c|c|c|c|}
\hline \multicolumn{3}{|c|}{$\begin{array}{l}\text { Treatment per } \\
\text { acre with }\end{array}$} & \multicolumn{6}{|c|}{ Nutrient content, dry-weight basis, for varieties indicated? } \\
\hline $\mathbf{N}$ & $\mathrm{P}_{2} \mathrm{O}_{6}$ & $\mathrm{~K}_{2} \mathrm{O}$ & Sea Island & Pima 32 & Coastland & Sealand & Amsak & $\underset{\text { varieties }}{\text { Mean of } 5}$ \\
\hline
\end{tabular}

Leaf nitrogen $(N)$

\begin{tabular}{r|c|c|c|c|c|c|c|c}
\hline$L b$. & Lb. & Lb. & Percent & Percent & Percent & Percent & Percent & Percent \\
0 & 200 & 200 & $3.91(85)$ & $4.87(87)$ & $3.67(84)$ & $4.17(69)$ & $4.21(77)$ & $4.17(84)$ \\
200 & 200 & 200 & $4.49(100)$ & $4.86(100)$ & $4.63(100)$ & $4.48(100)$ & $5.08(100)$ & $4.71(100)$ \\
\hline
\end{tabular}

Leaf phosphorus $(P)$

\begin{tabular}{r|r|c|c|c|c|cc|c|c}
\hline 200 & 0 & 200 & $0.42(90)$ & $0.38(71)$ & $0.34(85)$ & $0.32(84)$ & $0.47(81)$ & $0.39(83)$ \\
200 & 200 & 200 & $.45(100)$ & $.40(100)$ & $.36(100)$ & $.29(100)$ & $.43(100)$ & $.39(100)$ \\
\hline
\end{tabular}

Leaf polassium $(K)$

\begin{tabular}{r|r|r|l|l|l|l|l|l}
\hline 200 & 200 & 0 & $2.36(98)$ & $2.28(85)$ & $1.69(102)$ & $1.93(92)$ & $2.18(87)$ & $2.09(93)$ \\
200 & 200 & 200 & $2.70(100)$ & $2.30(100)$ & $2.14(100)$ & $2.11(100)$ & $2.25(100)$ & $2.30(100)$ \\
\hline
\end{tabular}

1 Leaf samples taken 73 days after planting.

${ }^{2}$ Numbers in parentheses show the relative yield of seed cotton per acre associated with the indicated fertilizer treatment and variety.

It would be interesting to compare our leaf values obtained from Sea Island cotton on Altura loam (table 7) with the same variety on the Santa Isabel clay (table 8). However, before we can do so, we must adjust the leaf values of the Santa Isabel clay, because they were taken 73 instead of 45 days after planting. Although we have no exact formula to adjust for age, we can use as a guide the decrease in leaf values with age given in table 7. We find here that 45 days difference produced an average decrease of 1.15 percent in leaf nitrogen. Therefore, for 28 days, the decrease is 0.72 percent. This value can be added to the leaf-nitrogen values for Sea Island cotton in table 8 in order to bring these leaf samples to a base of 45 days of age. For no-nitrogen, we obtain a leaf-nitrogen value of 4.63 ; and for 
200 pounds of nitrogen per acre, we get 5.21 percent. Thus, for a relative yield of 85 , we have a leaf-nitrogen value of 4.63 ; for the Altura loam (table 7), a relative yield of 89 was associated with a leaf-nitrogen value of 4.76 . For the Santa Isabel clay, a relative yield of 100 was associated with a leaf value of 5.21, and for the Altura loam, the same relative yields was related to 5.10 percent of leaf nitrogen.

Inasmuch as the percentage change is small for leaf phosphorus we may compare the two experiments without adjusting leaf values. The phosphorus leaf-values of the Santa Isabel clay were a bit higher than those for the Altura loam (tables 7 and 8), but no significant response was obtained to phosphates in either soil.

The leaf-potassium values were adjusted to a basis of 45 days sampling for the Lajas experiment by using a factor of 0.51 leaf potassium to be added for the 28-day difference in sampling time. For no-potash adjusted, leaf potassium became 2.87; and for 200 pounds of $\mathrm{K}_{2} \mathrm{O}$ per acre, 3.21. These adjusted values compare favorably with those obtained for the Altura loam (table 7). In neither soil were responses to potash fertilizers significant.

\section{SUMMARY}

The results of the six fertilizer experiments with cotton carried on at Isabela, Aguirre, and Lajas, from 1943 to 1956, indicated that:

1. Cotton growing in Guayabo fine sand responded to phosphate and potash fertilizers. The use of 1,000 pounds of $5-10-10$ per acre was recommended for this soil.

2. The use of nitrogen at 82 pounds per acre produced the only significant response to fertilizers for a Coto clay.

3. Cotton growing in Altura loam responded significantly only to applications of 100 pounds of nitrogen per acre.

4. Cotton growing on a Santa Isabel silty clay loam did not respond to nitrogen, phosphates, nor potash fertilizers.

5. The fertilizer demands of cotton growing in Santa Isabel clay appeared to be highest for nitrogen and phosphates, with no response to potash. The intensity of these needs varied somewhat with the cotton variety planted.

6. Leaf-blade rather than the petiole tissue was found to be most reliable for foliar analyses in determining the appropriate levels of nitrogen, phosphorus, and potassium in the plant tissue.

7. Leaf samples taken 45 days after planting revealed the greatest difference in response to fertilizers as compared to 60 and 90 days.

8. For tentative use as leaf standards for Sea Island cotton: It is suggested that leaf blades containing, on a dry weight basis at 45 days after planting, above 5.00 percent of nitrogen should show no response to addi- 
tional nitrogen; above 0.40 percent of phosphorus, no response to phosphates; and, above 3.20 percent of potassium, no response to potash.

\section{RESUMEN}

Los resultados de cinco experimentos sobre el abonamiento del algodón se resumen como sigue:

1. El rendimiento de algodón respondió a la aplicación de los abonos fosfatados y potásicos en el suelo del tipo arena fina Guayabo.

2. Sólo hubo reacción significativa con el uso de 82 libras de nitrógeno por acre en el suelo del tipo Coto arcilloso.

3. Sólo hubo reacción significativa cuando se hicieron aplicaciones de 100 libras de nitrógeno por cuerda en el suelo del tipo Altura lómico.

4. El rendimiento del algodón no respondió a las aplicaciones de nitrógeno, fosfatos, ni potasa en el suelo del tipo Santa Isabel limoarcilloso lomico.

5. Tal parece que la necesidad del suelo del tipo arcilla Santa Isabel es mayor por nitrógeno y fosfatos en cuanto al algodón. No respondió a las aplicaciones de potasa. La intensidad de las exigencias de la planta por estos abonos varió algo según la variedad.

6. Fué la hoja en vez del pecíolo de la planta que resultó mejor para el análisis foliar, en lo que respecta a los niveles de nitrógeno, fósforo y potasio en sus tejidos.

7. Muestras de hojas tomadas a los 45 días de sembrado el algodón, revelaron la diferencia mayor en su reacción a la aplicación de los abonos, al compararse con las muestras que se tomaron a los 60 y a los 90 días.

8. Para uso tentativo, como estándar de hojas para el algodón Sea Island, se sugiere que éstas sean analizadas a base de peso en seco a los 45 días de haber sido sembradas las plantas. Sobre 5.00 por ciento de nitrógeno no deben dar señales de responder al nitrógeno, sobre 0.40 por ciento a los fosfatos y sobre 3.20 por ciento a la potasa.

\section{LITERATURE CITED}

1. Aguilar, P. J., Report of the President, 1955-57, Puerto Rico Cotton Grower Marketing Cooperative pp. 1-8, Apr. 30, 1958 (mimeographed).

2. Capó, B. G., A new method for performing field trials, J. Agr. Univ. P.R. 28 (1) 22-34, 1944.

3. Capo, B. G., Samuels, G., Landrau, P., Jr., Alers-Alers, S., and A. Riera, The Method of Foliar Diagnosis as Applied to Sugarcane: Part II The Chemical Analysis of Sugarcane Leaf Samples, Agr. Exp. Sta. Univ. P.R. Bul. 123, Feb. 1955.

4. Chardón, F., Annual Report of the Assistant Agronomist for Cotton, Annual Report, Agr. Exp. Sta. Univ. P.R. fiscal year 1930-31, 1932.

5. Joham, H. E., The nutritional status of the cotton plant as indicated by tissue tests, Plant Physiol. 26 (1) 76-89, 1951. 
6. Landrau, P., Jr., and Samuels, G., Response of four sugarcane varieties to fertilizers during the first Isabela cycle, 1946-51, J. Agr. Univ. P.R. 39 (2) 77-83, 1955.

7. - Influence of fertilizers on the yield of the Plamar variety of tomatoes on a Coto clay, J. Agr. Univ. P.R. 39 (2) 77-83, 1955.

8. Pastor Rodríguez, J., Gandía-Caro, R., and Vásquez-Romero, R., Cotton variety trials in Puerto Rico, J. Agr. Univ. P.R. 40 (1) 49-61, 1956.

9. Samuels, G., The influence of the age of sugarcane on its leaf-nutrient content, (to be published later in J. Agr. Univ. P.R).

10. Samuels, G., Alers-Alers, S., and Jackson, G. C., Influence of fertilizers on yields of pineapples on a Coto clay, J. Agr. Univ. P.R. 42 (1) 12-26, 1958.

11. Samuels, G., Landrau, P., Jr., and Olivencia, R., Response of pineapples to the application of fertilizers, J. Agr. Univ. P.R. 39 (1) 1-11, 1955. 